\title{
Conditionality and Compliance: The Shaky Dimensions of NATO Influence (The Georgian Case)
}

\author{
Shalva Dzebisashvili *
}

\section{Introduction: The Puzzle}

It is no secret that NATO exerts global influence, and is an organization without which the international security architecture would be difficult to imagine. Its capacity to exert influence ranges from the very material dimension of military power to the elusive and intangible effects of functional professionalization. Its unifying power was recognized long before the fall of the Berlin Wall, motivating Karl Deutsch to assign to it the quality of the "Community" in the North Atlantic area. ${ }^{1}$ The paradigm of the Cold War heavily influenced the way scholarship evaluated the Alliance. Despite numerous and valuable attempts, the majority of academic contributions to the study of NATO remained policy-driven. The discussion was subsumed by broader regional security studies and international relations scholarship that repeatedly brought up the question of the Alliance's organizational purpose and durability, leaving other significant questions unexamined. ${ }^{2}$ This article will attempt to address the existing scholarly deficit by focusing on a particular aspect of NATO analysis: the Alliance's capacity to influence aspirant countries' policy making (formulation and implementation) in the defense area and, by doing that, to ensure compliance with commonly agreed norms and standards.

The case of Georgia would serve here as the best example of a country that eagerly stated its willingness to join NATO (as early as the Prague Summit in 2002) and since then has firmly followed the chosen path towards full membership. ${ }^{3}$ The time span (nine years) to review is sufficient to disregard the risk of early or premature statements that would be symptomatic of early stages of cooperation. The intensity and density of the relationship between NATO and the Georgian Ministry of Defense led to the creation of a complex set of issue areas in which the processes of integration have unfolded, and the national/domestic constituencies have been exposed to various modes of external insti-

Shalva Dzebisashvili received an EU Commission doctoral fellowship (GEM) in September 2012 and currently is a Ph.D. researcher at the Institute for European Studies (IEE-ULB). He is member of the Civil Council on Defense and Security (CCDS), a non-governmental organization founded in Georgia. In 2008-09 he successfully completed an M.A. course in Strategic Security Studies at the NDU (Washington D.C.) and consequently took over the position of Senior Civilian Representative of Georgian MOD (Defense Advisor) to the Georgian Mission to NATO.

1 Karl W. Deutsch, et al., "Political Community and the North Atlantic Area," in The European Union: Readings on the Theory and Practice of European Integration, ed. Brent F. Nelsen and Alexander Stubb, 3rd ed. (Boulder, CO: Lynne Rienner Publishers, 1957).

2 Mark Webber and Adrian Hyde-Price, "Theorizing the North Atlantic Treaty Organization," in Joint Sessions of Workshops (Lisbon, 2009), 1.

3 Ministry of Foreign Affairs of Georgia, n.d.; available at http://mfa.gov.ge/index.php?lang $\mathrm{id}=\mathrm{GEO} \&$ sec_id $=453$. 
tutional influence. The question of national compliance is inherently related to the concept of conditionality, due to the core principle of agreement between two actors, where one gets rewarded by another if certain conditions (i.e., commitments) are fulfilled. ${ }^{4}$ Thus, by highlighting particular aspects of defense cooperation between the Alliance and Georgia, we hope not only to provide more insight into the ability of the Alliance to apply various mechanisms of compliance, but also to examine the limitations of those mechanisms, as well as the domestic factors and political incentives that either supported the national decision to comply or in fact impeded any decisions, leading to domestic political cleavages and to a heightening of international (NATO) concerns.

The essay is designed in such a way as to provide first a brief overview of the literature on NATO and its inherent deficits from the standpoint of influence on aspirant countries' decisions. Second, we will operationalize the concept of NATO conditionality in order to devise our line of argument and the hypothesis, to delineate the core objectives that an aspirant country such as Georgia must reach in the area of defense, and to demonstrate the practical utility of existing institutional mechanisms in reaching those objectives. Next we will try to validate the achievements of the Georgian Ministry of Defense (henceforth Geo MOD) by looking at various data sources, often not directly related to defense. Obviously, the high sensitivity of security-relevant issues meant that most of the relevant data reside in classified records, significantly reducing the amount of publicly accessible information. Nevertheless, the pool of sources containing disclosed official documents, legal acts, media interviews, official statements, news, etc. provide a solid foundation for launching our analytical investigation. Last, we will carefully sort out the effects of conditionality (positive compliance, and negative non-compliance) caused by NATO from those caused by domestic factors (incentives and calculations) in order to establish a high degree of causal relationship between external influences (conditionality) and domestic effects (compliance).

\section{Conceptual Deficits of the NATO-related Literature}

Scholarship on NATO has been largely structured by the classical divide between the realist and constructivist stands. Various theoretical approaches have been adopted to test the validity of NATO-related claims, from both mainstream perspectives. ${ }^{5}$ The key element of the realist approach, which is the struggle for power and dominance as the rationale for state survival, was seriously challenged after the collapse of the major communist foe. Realist authors regarded government action as a rational choice in the strategic environment of international politics. ${ }^{6}$ Thus they questioned the durability and

4 Jeffrey T. Checkel, "Compliance and Conditionality," ARENA Working Papers No.18 (2000); available at www.sv.uio.no/arena/english/research/publications/arena-publications/ workingpapers/working-papers2000/wp00_18.htm.

5 Webber and Hyde-Price, "Theorizing the North Atlantic Treaty Organization," 1.

6 Robert G. Kaufman, "Review of Alan C. Lamborn and Stephen P. Mumme, Statecraft, Domestic Politics, and Foreign Policy Making: The El Chamizal Dispute," The Journal of Politics 51:3 (August 1989): 791. 
the very purpose of the preservation of the key Western military alliance-NATObased on the assumption of diverging interests of its member states in post-Cold War era (a view articulated by such prominent realist scholars as John Mearsheimer, Kenneth Waltz, Steven Walt, and Robert Kagan). ${ }^{7}$ Joseph Grieco offered the "amended prisoners' dilemma" as an alternative view, which provided a more penetrating analysis of the limitations of international cooperation while preserving the realist underpinning of state behavior. He accurately depicts the complex relationship between the rank ordering of relative payoffs (gains) and the defined set of sensitivity factors, which leads him to conclude that states will refuse, limit, or abandon cooperative commitments if they expect their relative gains to be disproportionately low. ${ }^{8}$ The sociological foundation of global power politics and cooperation, so vehemently rejected before, slowly found cautious recognition within rationalist authors' claims. Though the principle of interestbased behavior remained unchanged, it appeared to be fully plausible now that while forming alliances, great powers would seek like-minded partners regardless of their relative power, or cooperate (band-wagoning) and advance shared interests based on internal regime similarity. ${ }^{9}$

The new refreshing elements mentioned here are very important to distinguish new approaches from the traditional realist approach, and are relevant to the concepts of conditionality and compliance we want to apply to the NATO-Georgia case. Furthermore, they serve as powerful points of reference when they are applied alongside arguments developed by proponents of the other rationalist school - that of neoliberal institutionalism, which stresses the relevance of domestic constituencies, incentives, and cost calculations while deciding on particular modes of international behavior: compliance or defection. Correctly labeled by Michael McFaul as the "forgotten dimension," the international factors of domestic change are essential to help us establish causal linkages between domestic actors and external agents. ${ }^{10}$ Interestingly enough, however, the focus on effects caused domestically by external actors - or, conversely, the domestic sources of international behavior - receive less attention in liberal scholarship as it is applied to international security institutions in general, and NATO in particular. The realm of economic cooperation has been intensively studied by neoliberal scholars, who have generated brilliant analysis on conditionality and compliance on the examples of state cooperation within GATT, WTO, and EU. They rendered exceptionally strong general pro-

7 Erik Voeten, "Resisting the Lonely Superpower: Responses of States in the United Nations to U.S. Dominance," The Journal of Politics 66:3 (August 2004): 733.

8 Joseph M. Grieco, "Realist Theory and the Problem of International Cooperation: Analysis with an Amended Prisoner's Dilemma Model," The Journal of Politics 50:3 (August 1988): 601-03.

9 Kevin Sweeney and Paul Fritz, "Jumping on the Bandwagon: An Interest-Based Explanation for Great Power Alliances,” The Journal of Politics 66:2 (May 2004): 429-40.

10 Michael McFaul, Amichai Magen, and Kathryn Stoner-Weiss, Evaluating International Influences on Democratic Transitions: Concept Paper (Stanford, CA: Center on Democracy, Development and the Rule of Law, 2007), 6,7; available at http://www.bangalured.net/world/ Evaluating_International_Influences_-_Transitions_-_Concept_Paper.pdf. 
positions that are worthy of application in other functional areas. For instance, Andrew Moravcsik holds that national governments are exposed to the influence of domestic interest groups and are committed to respond to their demands via various mechanisms of representation (democratic, social etc.). ${ }^{11}$ This aspect (among others) is also included by Robert Putnam in his more developed system of the interplay of international political negotiations (a two-level game), in which national executives are involved in reaching an international agreement. While it is implicit within this model, the conflict of internal and external (international) agendas poses a serious issue of political concern that deserves much more attention, both theoretically and practically.

Unfortunately, the literature related to security organizations and NATO fails to devote the same degree of interest to the domestic sources of state behavior, largely keeping the main focus on the problem of intra-institutional coordination, institutional adaptation, as well as the durability of the Alliance. Still, it is possible to formulate a common approach of institutionalist scholarship to security and military alliances. They are designed in purposeful way "in part to regulate internal political dynamics," but most importantly they represent and serve as regimes, reflecting norms and expectations of behavior. ${ }^{12}$ This may well serve as the general framework of reference for the further application of the conditionality/compliance concept. Using Mark Webber's words, a good theoretical approach can help to diagnose, predict, and prescribe. ${ }^{13}$ Indeed, we need valuable insights from different scholarly mainstreams to discover single arguments, categories, or analytical concepts that-once applied in a coherent mannerwould provide convincing explanations of particular social and political phenomena, which in turn may have significant effects on policy formation and implementation. To do so, we need to identify additional areas of the academic literature where the significant correlation of similar factors can be observed, and successful borrowings can be made. The notion of domestic constituencies, local interests and incentives, as well as the highly theoretical notion of "relative gains" (payoffs) represents pretty much the core of the discussion in the democratization literature. The international dimension of cooperation is another pillar of democratization scholarship. As Robert Putnam aptly puts it, international commitments require domestic ratification, and this may be limited due to the democratic nature of the country and the need of the governments to secure electoral

11 Andrew Moravcsik, "Taking Preferences Seriously: A Liberal Theory of International Politics," International Organization 51:4 (1997): 518.

12 Andrew G. Long, Timothy Nordstrom, and Baek Kyeonghi, "Allying for Peace: Treaty Obligations and Conflict between Allies," The Journal of Politics 69:4 (November 2007): 103-04. See also McFaul, Magen, and Stoner-Weiss, Evaluating International Influences on Democratic Transitions, 12.

13 Mark Webber, "Theorizing NATO - More than a Defence Alliance?" paper presented at the conference "NATO at 60: Reflecting on the Past - Anticipating the Future Wednesday," Copenhagen (11 March 2009), 7; available at http://subweb.diis.dk/graphics/Events/2009/M. Webber_NATO_at_60_DIIS.pdf. 
support. ${ }^{14}$ In other words, if international commitments and promises have been given without the proper consideration of the preferences of domestic players, a significant backlash can be expected in a country that enjoys a sufficient level of democracy. A strong link between the notions of conditionality and compliance is the pivotal element of most democratization studies, in particular within the context of EU enlargement. We do not intend to list the universe of authors and their contributions to the topic here, yet we will briefly sketch out the general results of their studies to enhance the common understanding of the processes that accompany the policy of conditionality.

The driving force of successful cooperation within the institutional framework is, clearly, the readiness of the actor (i.e., the state) to accept common procedures and policies that might well be generated outside the institution yet constitute the logic of appropriateness related to the individual behavior. For instance, in the field of democratic studies the principle of adherence to democratic standards and norms is given great importance. The process of democratic transition usually involves an institution that is still influenced by rules that conflict with the new requirements, and often results in a continuous adaptation to context and learning mechanisms, through which positive results can be achieved. ${ }^{15}$ Being aware that a successful transition is not guaranteed and is contingent on multiple factors, scholars of democratization studies rightly identified the concept of conditionality as the key element of the causal relationship between EU membership aspirations and real achievements. Understanding the external factors of influence in domestic affairs became crucial to success. Yet, among other factors, the prospect of membership alone proved to be the strongest incentive for democratic transformation and consolidation in Eastern Europe ${ }^{16}$ Furthermore, the membership promises, though critical, require additional features to help speed up or maintain the pace of a given country's transformation. Lisa Martin isolates three core elements of national compliance that ensure the high probability of successful democratic consolidation: the degree of credibility of state commitments, the effectiveness (effects) of the agreement, and the role of sanctions. ${ }^{17}$ Obviously, the second and third factors are also highly relevant to the concept of conditionality; in fact, they are the essence of it. We might also use the term "transformative engagement" to highlight the fluid nature of the processes, which are still highly contingent on the results achieved. ${ }^{18}$

Though many authors recognize the existence of and the need for further elaboration of constraining measures to bring about compliance and punish uncooperative behavior,

14 Robert D. Putnam, "Diplomacy and Domestic Politics: The Logic of Two-Level Games," International Organization 42:3 (Summer 1988): 36-37.

15 Ole Norgaard, "Democracy, Democratization and Institutional Theory," DEMSTAR Research Report 4 (December 2001): 3-5.

16 Jon C. Pevehouse, Democracy from Above: Regional Organizations and Democratization (Cambridge: Cambridge University Press, 2005), 96.

17 Lisa L. Martin, Democratic Commitments: Legislatures and International Cooperation (Princeton, NJ: Princeton University Press, 2000), 225.

18 McFaul, Magen, and Stoner-Weiss, Evaluating International Influences on Democratic Transitions, 12 . 
most of the attempts to produce more insight on the effectiveness of NATO mechanisms applied to aspirant countries have remained fairly unconvincing and vague. ${ }^{19}$ Frank Schimmelfennig, who is perhaps the most prominent writer in the democratization field, is not an exception in this regard. His contributions represent brilliant work illustrating the complexity of the social and political socialization of the aspirant countries' executive officials during the period of intensive negotiations with EU executives. Yet, despite his exemplary findings that favor interest-based explanations of the European policy of conditionality, the problem of scant evidence on the motives behind the commitment to domestic transformation remains unresolved. ${ }^{20}$ Thus we suggest identifying the key findings we were able to distill so far, and infuse them in our analytical concept (to be introduced in the following section) as a cementing substance for the purpose of analytical clarity and cohesiveness.

\section{Analytical Concept: Conditionality-Implied Compliance (CC)}

As was briefly mentioned before, the objective of our analytical concept has primarily to be regarded as providing an analytical tool that will facilitate the proper understanding of NATO-conditionality as applied to the case of Georgia as an aspirant country. Additionally, we intend to illustrate the close affinity of the category of compliance to the overall concept of conditionality, for which we will use henceforth the abbreviation "CC" (Conditionality and Compliance).

Clearly, every social phenomenon is a unique process, with its own historical context that is not likely to reappear in other settings. ${ }^{21}$ This fact, however, should not prevent us from applying valid propositions to case-study examples of NATO member accession, which most probably will result in even more valuable findings, bringing us closer to the truth. Bearing this in mind, we will focus our attention on a number of categories that appear to be most critical to the $\mathrm{CC}$ concept. First we will examine the notions of Incentive and Relative Gains (payoffs), due to their close contextual and semantic relationship to state interests. Celeste Wallander argues that strong incentives allow countries to conform to international norms. ${ }^{22}$ Naturally, the strength of the incentives will increase if they correlate with a given state's interests. Whenever states decide to engage an international organization (and NATO is not an exception here) or individual states within the organization, the question of the hierarchy of state interests for the mode of behavior becomes of utmost importance. From studying the processes of NATO enlargement,

19 Voeten, "Resisting the Lonely Superpower: Responses of States in the United Nations to U.S. Dominance"; Mark Kramer, "NATO, the Baltic States and Russia: A Framework for Sustainable Enlargement," International Affairs 78:4 (October 2002): 731-56; Frank Schimmelfennig, "NATO's Enlargement to the East: An Analysis of Collective Decision-Making," EAPC-NATO Individual Fellowship Report 2000 (1998): 1-75.

20 Schimmelfennig, "NATO's Enlargement to the East," 66.

21 James J. Wirtz, "Review of Patricia A. Weitsman, Dangerous Alliances: Proponents of Peace, Weapons of War," The Journal of Politics 69:1 (February 2007): 258.

22 Celeste A. Wallander, "Institutional Assets and Adaptability: NATO after the Cold War," International Organization 54:4 (2000): 709. 
Franks Schimmelfennig concludes, "in this account, the alliance identity and norms had no independent effect on the enlargement outcome but simply happened to be in line with the preferences of the most powerful actor(s)." ${ }^{23}$ Admittedly, this statement bluntly challenges the whole concept of $\mathrm{CC}$, and once more underlines the strength of the interest-based argument of some enlargement studies. Preferences are also often identified as expected payoffs from certain decisions, and thus as subject to rational choices made by a state. ${ }^{24}$ They must be substantial in order to be detected by the state, and in the bestcase scenario should correlate with existing incentives to ensure rapid action and implementation. Incentives are rewards offered by an external actor (in this case, NATO) in exchange for compliance; however, they also exist in the domestic realm, and together with potential gains at this level offer a powerful alternative lever to influence state behavior. Domestic interests (preferences) and constituencies play crucial roles in creating such behavioral alternatives, ranging from full compliance to partial compliance to noncompliance. The conflict between external and domestic might be very real, and can clearly illustrate the existing problems in preference orderings. We readily join at this point Stephen Krasner's statement (with slight amendment) that the key question is how essential and strategic are the objectives to be achieved, both for the external actor as well as for the state. ${ }^{25}$ Since the prospect of membership is the only substantial incentive "carrot" the institution can offer - and it is at the same time the "stick" that the institution wields (through the threat of withholding membership) - the probability of real influence being exerted on the candidate must be assessed as high, ${ }^{26}$ according to Janine Reinhard. ${ }^{27}$ Applying this logic to the NATO-Georgia case, where the prospect of membership at first glance is neither imminent nor procedurally guaranteed, the causal relationship between the membership promises and the democratic transformation of the Georgian defense sector seems to be problematic. On the other hand, the priority ranking of conditions, assumed to be carried out the by candidate, must be thoroughly studied; such study may render surprising conclusions that are contrary to our initial expectations.

State interests may be well defined and clearly identified, but this does not mean that the state's preferences and priorities have been thoroughly calculated. The decision-

23 Schimmelfennig, "NATO's Enlargement to the East," 65.

24 Voeten, "Resisting the Lonely Superpower: Responses of States in the United Nations to U.S. Dominance," 732.

25 Stephen D. Krasner, "International Support for State-Building: Flawed Consensus," PRISM Security Studies Journal 2:3 (June 2011): 65-74.

26 We use the terms candidate and aspirant interchangeably; however, within the NATO context, they refer to different categories. Candidate status is given to country that is under a Membership Action Plan and is formally recognized as next in line to become a full member, whereas the status of aspirant countries does not imply formal recognition of any timeframes of accession, not to mention the prospect of imminent membership.

27 Janine Reinhard, "EU Democracy Promotion Through Conditionality in its Neighbourhood: The Temptation of Membership Perspective or Flexible Integration," Caucasian Review of International Affairs 4:3 (2010): 197. 
making process that leads to the preference orderings is also very difficult to observe. ${ }^{28}$ We might detect the various steps in this process by noting the various decisions and actions state officials are involved in; nevertheless, the ability to prove and measure the level of compliance at the functional level of bureaucracy still remains in the realm of wishful thinking. The problem of indication and measurement is twofold. On one hand, $\mathrm{CC}$ conditions must be clear, mechanisms of control of adherence must be identified, and the measurement must be performed transparently in a periodic manner. ${ }^{29}$ An additional challenge is the fact that the security and defense sector by its nature cannot be fully transparent. Understandably, information about the effectiveness of the defense transformation process and the degree of implementation of external commitments in various functional areas can be of a very sensitive nature, and thus would be classified. Unfortunately the credibility of national commitments can be validated only through imperfect mechanisms of implementation that in turn require close analysis and thorough interpretation of data. Finally, we are not immune from cases where $\mathrm{CC}$ results in formal implementation at the national level but leaves the essence of the domestic "code of conduct" unaffected. ${ }^{30}$ Indeed, the danger of formality has several dimensions, each potentially detrimental to the success of CC. It might take the form of a purely formal commitment, without any domestic consequences. Or it can take the form of formal compliance, meaning the initiation of certain regulations and legal provisions that provide the impression of practical compliance, though still lacking the proper dimensions of real-life implementation. Finally, we might find some evidence of implementation, but of sporadic and phony nature that is very easy to reverse.

Based on the key elements of the $\mathrm{CC}$ concept we have formulated above, and the intrinsic limitations of CC concept measurement, we suggest at this point that we may regard the concept as a general analytical construct that is largely dependent on the interplay between external/domestic incentives and the expected relative payoffs that are either negative or positive, and can lead to positive effects on state behavior (i.e., compliance) or negative effects (i.e., non-compliance; see Table 1). In the course of analysis, we expect to introduce more elements to this model, once more light is shed upon the mechanisms and motives of a particular behavior. Consequently the final, more developed chart will be presented in the concluding part of the paper, visualizing the key data and causality lines within the effects of $\mathrm{CC}$.

Within this logic, we found it problematic to concur with the basic sociological hypothesis, which argues that the faster that common norms and values are adopted, the earlier the prospect of membership will be offered. ${ }^{31}$ Leaving aside the case of Turkey in NATO, where a serious critique is directed towards the state's obvious lack of adherence to the norms of liberal democracy, we offer the following hypothesis:

28 Voeten, "Resisting the Lonely Superpower: Responses of States in the United Nations to U.S. Dominance," 731.

29 Reinhard, "EU Democracy Promotion Through Conditionality in Its Neighbourhood," 202.

30 Ibid., 203.

31 Schimmelfennig, "NATO's Enlargement to the East," 8, 11. 
Table 1. Conditionality and Compliance: Incentives vs. Expected Payoffs

\begin{tabular}{|l|l|l|}
\hline & Domestic factors / incentives & $\begin{array}{l}\text { External factors / incentives } \\
\text { (conditions) }\end{array}$ \\
\hline Positive payoff & & \\
\hline Negative payoff & & \\
\hline $\begin{array}{l}\text { Positive effect } \\
-(\text { compliance) }\end{array}$ & & \\
\hline $\begin{array}{l}\text { Negative effect } \\
\text {-(non-compliance) }\end{array}$ & & \\
\hline
\end{tabular}

If the value of an external incentive cannot outweigh the cost calculations of a domestic action, compliance will not take place and conditionality will fail. In other words, if the relative gains to be realized by pursuing a state's external commitments are lower than the expected payoffs from a conflicting domestic action, compliance will not take place, resulting in a failure of conditionality.

To prove the validity of our claims, we must once again touch upon the problem of measurement indicators. What mechanisms do we need to prove the degree of compliance, and how can we avoid the risk of "buying" formal commitments and compliance (known as Masking) for real implementation? Out of the many mechanisms of foreign influence offered by Pevehouse, we choose legitimization and political pressure as the most promising avenues for further investigation as behavioral motives. ${ }^{32}$ The particular aspect of financial assistance can be generally disregarded, due to the bilateral nature of financial assistance and the inherent difficulty in tying a concrete military/structural output to a particular source of financing. As suggested by Lisa Martin, the role of the legislature in affecting the credibility of national commitments should not be underestimated, since it provides valuable information on the legal status and prospects of compliance. ${ }^{33}$ Additionally we will look at other initiatives generated within NATO to widen the spectrum of analysis and reduce the danger of limitation in primary sources that is so familiar to scholars working in the sensitive fields of security and defense.

\section{Objectives and Preference Orderings (NATO vis-à-vis Georgia)}

This section of the essay will examine the strategic nature of the formal objectives pursued by NATO and Georgia, review actual policy priorities, and attempt to establish a general picture that would either prove the high degree of congruence between the policy objectives of both actors or indicate the existing (and widening) lack of alignment of

32 Pevehouse, Democracy from Above, 3-26.

33 Martin, Democratic Commitments: Legislatures and International Cooperation, 225. 
their political agendas. In doing so, we will naturally refer to official documents and statements, as well as media interviews, reports, and communiqués to establish a normative foundation for further analysis of the processes at the functional level of the defense ministry.

The NATO membership has been increasingly defined through reference to a community whose borders are defined not by geography, but rather by a common identity, cultural tradition, and solid portion of trust to each other. In particular, democratic institutions (including norms and procedures) are seen as serving the primary cementing function for the Alliance. ${ }^{34}$ Former British Foreign Minister Ernest Bevin, as well as Walter Lippman, readily focused on the aspects of "spiritual" unity and civilizational similarity to underline the cognitive roots of NATO's creation. ${ }^{35}$ Those principles gained even more relevance once the military aspect of global confrontation radically diminished in the early 1990s. The guiding criteria for future membership (introduced in 1995) remained the same, and largely refer to adherence to democratic principles and procedures that prospective member states need to adopt. ${ }^{36}$ The core importance of democratic values and of functioning democratic institutions also became a major motivational factor for justifying the Alliance's enlargement plans. While highlighting the internal aspects of negotiation and decision making of the first former Warsaw Pact countries that joined the Alliance, Frank Schimmelfennig very quickly comes to the conclusion that adherence to democratic rule and norms represented the constitutive values of NATO and facilitated the recognition of democracy promotion as the organizational mission of the Alliance. ${ }^{37}$ The "Study on NATO Enlargement" states explicitly four times the importance of "like-mindedness" and twice the need for the "assimilation" of new members. ${ }^{38}$ Out of eight political-economic requirements for potential membership, three unequivocally stress the primacy of democratic rule and institutions, and one directly advises aspirant states to commit to social justice and economic liberty. ${ }^{39}$ What this means in terms of practical implementation and procedural compliance will be the subject of next section of this essay. At this stage, we are primarily interested in understanding how the Georgian government and leadership have been able to reflect the mentioned aspects of NATO identity in their legal and normative dimensions of policy formulation, particularly in the specific field of defense.

34 Christopher Hemmer and Peter J. Katzenstein, "Why Is There No NATO in Asia? Collective Identity, Regionalism, and the Origins of Multilateralism," International Organization 56:3 (2002): 575, 588 .

35 Ibid., 597-600.

36 Kramer, "NATO, the Baltic States and Russia: A Framework for Sustainable Enlargement," 736; "NATO - Enlargement," NATO website; available at http://www.nato.int/cps/en/ natolive/topics_49212.htm.

37 Schimmelfennig, "NATO's Enlargement to the East," 1-2.

38 "NATO - Study on NATO Enlargement," NATO website; available at http://www.nato.int/ cps/en/natolive/official_texts_24733.htm.

39 "NATO - Membership Action Plan (MAP)," NATO website; available at www.nato.int/cps/ en/natolive/official_texts_27444.htm. 
Since presidential authority represents the highest point in the executive pyramid in Georgia, it seems no surprise that we began our analysis with the documents posted on the president's website (the website has been completely changed after new President was elected in October 2013). Interestingly enough, out of 215 contributions related to NATO, only one could be formally regarded as an official document (a record of a speech that was similar to other summaries of presidential speech records). A close study of those transcripts reveals an appalling deficit in the formulation of Georgia's prospective NATO membership within the framework of common identity and shared democratic values. NATO is almost exclusively regarded as a security institution providing security guarantees, and as an important justification for meeting certain standards of military-technical interoperability. ${ }^{40}$ On various occasions, whether at NATO multilateral or bilateral meetings, or during visits with national officials from member states (including a visit to Georgia's major strategic partner, the United States) President Saakashvili's core messages disregarded the value-based perception of the Alliance, and nearly completely avoided mentioning the transformation of Georgia's defense sector in accordance with democratic principles. ${ }^{41}$ Some excerpts are worthy of mention here: "Undoubtedly, our goal is NATO integration, since Georgia is not only a user of a security system. For me, as a democratically elected leader of my country, the main audience are people, rather than any expert or international organization." 42

The statement was made as the president addressed the Georgian Security Forum in his welcoming speech. Setting aside the emotional aspect of the text, a clear neglect of the international dimension of control or compliance is evident nevertheless. The security prism through which NATO has been perceived by the Georgian leadership has not changed, even after the debacle of the 2008 war with Russia, and has continued to influence the formulation of Georgian policy, leading to the understanding of its primary relevance to the defense sector as a means of upgrading the armed forces' skills, equipment, training doctrines, etc. ${ }^{43}$ We might agree to the objection that the intensity of political cooperation and the ever-faster pace of political events might result in disorientation and lessening of the strategic messaging. This is apparently not the case for NATO. All documents related to Georgia reaffirm the key importance of democratic transformation as the primary channel towards full membership. The backgrounder document on NATO-Georgia relations explicitly highlights this requirement:

As an alliance based on democratic values, NATO has high expectations of prospective new members and urges Georgia to continue to pursue wide-ranging reforms to achieve

40 The Administration of the President of Georgia, 15 March 2007; available at http://www.president.gov.ge/en/PressOffice/Documents?4952 (20 October 2013).

41 The Administration of the President of Georgia, 19 March 2008; available at http://www.president.gov.ge/en/PressOffice/News?3250 (20 October 2013).

42 The Administration of the President of Georgia, 18 February 2006; available at http://www.president.gov.ge/en/PressOffice/News?2685 (20 October 2013).

43 The Administration of the President of Georgia, 15 September 2008; available at http://www.president.gov.ge/en/PressOffice/News?3127 (20 October 2013); "The Administration of the President of Georgia," March 15, 2007. 
its goal of Euro-Atlantic integration. ... The Euro-Atlantic partnership is about more than practical cooperation - it is also about values. ... In doing so (signing the PFP Framework Document), partners commit to the preservation of democratic societies. ${ }^{44}$

After having carefully reviewed the official policy documents as well as interviews and other relevant sources, we were able to come up with the following findings. The National Security Council, as the leading body in crafting strategic security policy in Georgia, placed remarkably little emphasis on the aspect of common democratic identity as it relates to Georgia's NATO aspirations. The current National Security Concept views the Alliance solely as a mechanism for securing Georgia's independence and stable development. ${ }^{45}$ It seems that Georgia's Ministry of Foreign Affairs also tends to share this perspective, as it makes no reference to the unifying power of common values or identity. ${ }^{46}$ The Office of the State Minister on European and Euro-Atlantic Integration, according to its mission and functions, formally operates as the center of gravity for all Georgian state agencies dealing with NATO integration issues. Unfortunately, hopes to find any documentation coming from that office that would be relevant to our approach were quickly dashed, as the entire issue of national priorities and progress made towards NATO integration as well as the relevant reports are dramatically underrepresented at the office's webpage. ${ }^{47}$ As for the functional level of the Ministry of Defense, it was not surprising that the core body of its institutional documents - though they pay significant attention to the critical importance of the Alliance to Georgia-basically concentrated on the issue of interoperability of forces as the major factor of NATO cooperation. For instance, the current Minister's Vision 2013-2014 as well as the still in effect Military Strategy strengthen the value of capability developments in various military areas as key determinants to achieving military interoperability with NATO forces and ultimately full membership. ${ }^{48}$ A recently issued document on the status of defense transformation similarly avoided any explicit mention of values-related references within the context of NATO integration. ${ }^{49}$ The only powerful statement along these lines that we have been able to discover was the resolution of the Georgian Parliament on the major directions of the country's foreign policy. This document unambiguously interprets the Euro-Atlantic integration process of Georgia as the path towards strengthening

44 Deepening Relations with Georgia, NATO Backgrounder (Brussels: NATO Public Diplomacy Division, 2013), 1-3; available at http://www.nato.int/nato_static/assets/pdf/pdf_ publications/2013530_backgrounder_nato_georgia-eng.pdf.

45 National Security Concept of Georgia, n.d., 6; available at http://mod.gov.ge/documents/ cfgeyzvjwhgeo.pdf.

46 Ministry of Foreign Affairs of Georgia website.

47 The Office of the State Minister on European and Euro-Atlantic Integration, n.d.; available at http://eu-integration.gov.ge/index.php?que=eng/official_documents\#.

48 Minister's Vision 2013-2014 (Tbilisi: Ministry of Defense of Georgia, 2013), 7; available at http://mod.gov.ge/documents/476501Ministers\%20Vision\%20Geo.pdf; "National Military Strategy of Georgia," n.d., 1-3.

49 "Defence Ministry Becomes Transparent and Status of Transformation," Georgian Ministry of Defense, 2013; available at http://mod.gov.ge/documents/Modern\%20armed\%20forces.pdf. 
democratic institutions, rule of law, and individual liberties. ${ }^{50}$ Along with an interview given by the Defense Minister, Irakli Alasania, in which he recognizes the shortfalls of Georgia's democratic system from NATO's perspective, this parliamentary resolution is a rare example of anchoring the issue of democratic identity and shared common values in the agenda of official and policy-relevant documents. ${ }^{51}$

It is well known that Georgia's aspirations to NATO membership gained significant impetus after the National Movement Party came to power, and were reflected both in governmental structural changes as well as in major security and defense documents. It is fully comprehensible that such a change would be attributed to Georgia's rapidly worsening relationship with Russia. The Georgian leadership shared the common motivational understanding of joining alliances as a way of reducing the "probability of being attacked" (deterrence) and of preventing an "ally's alliance with one's adversary." 52 Despite the extensive focus on the key importance of the North Atlantic Alliance in safeguarding Georgia's independence and stability, close study of the relevant sources reveals an ambiguous picture of preferences existing among a range of national objectives. The mentioned parliamentary resolution is the only document placing Euro-Atlantic integration at the core of country's foreign policy, while recognizing its primacy among other foreign and security policy objectives. Contrary to that, the National Security Concept assigns Euro-Atlantic integration an unfortunate fifth place among Georgia's core national interests, whereas democracy and rule of law stand at only third place in the list of national values. ${ }^{53}$ While we do not wish to comment on the inherent failures of the document to present national values as key elements of the national way of life, we were surprised that among the nation's security policy priorities NATO integration ranked below "de-occupation" and the "improvement" of defense capabilities. ${ }^{54}$

Georgia's governmental websites exposed a general feature of frequent change since the practice of the quick turnover of governmental appointees became standard, resulting in the loss of previously posted information or documentary material. The Georgian Ministry of Defense is no exception in this regard. The earlier versions of the "Minister's Vision" document have been withdrawn, with the exception of the last one, which was amended and renewed under Irakli Alasania, the defense minister appointed by the new government in 2012. This short-term (2013-2014) policy paper lists the defense priorities of the ministry, and obviously assigns NATO integration the lowest importance due to its placement as last among the ministry's priorities. Furthermore, it is formulated in conjunction with the broader notion of enhancing international cooperation,

50 Resolution by the Georgian Parliament, 21 March 2013, chapters 3, 4; available at www.parliament.ge/index.php?option $=$ com_content\&view $=$ article\&id $=3136 \% 3$ Aresolution \& catid $=54 \% 3$ Astatements-appeals-and-resolutions \&Itemid=88\&lang=ge.

51 Interview with Georgian Defense Minister Irakli Alasania; available at http://mod.gov.ge/ index.php?pubid $=69$.

52 Schimmelfennig, "NATO's Enlargement to the East," 5.

53 National Security Concept of Georgia, 1,2.

54 Ibid., 1, 2. 
and is directly defined as focusing on the interoperability aspect of cooperation. ${ }^{55}$ Even if this is formally the case, even the single element of interoperability improvement within the NATO integration framework has to be considered here as equally relevant and not more important than other forms of bilateral or multilateral defense cooperation. The same tendency of neglect is evident in other chapters of the document, where nothing specific to the Alliance's importance is mentioned with regard to the priority of improving defense capabilities, or improving the NATO interoperability of Georgia's forces, not to mention the critical relevance of NATO requirements and standards. ${ }^{56}$ This clear-cut evidence of the uncoordinated efforts of Georgian institutions to reflect the proper significance of the Alliance for country's strategic foreign, security, and defense policies points either toward the absence of strong coordinating signals from the top of the government about the need of coherent national actions, or the inability of government branches to detect and correct the policy inconsistencies. It also has and will have continuing effects on the pace of integration in the Alliance, since the theoretical primacy of territorial integrity over the nation's Euro-Atlantic aspirations would imply the accession process to be initiated once Georgia's sovereignty over its breakaway regions has been restored, and not vice versa.

As for the implications of real-world political actions, some authors highlight the preponderance of the preservation of territorial integrity as the key legitimizing factor for the Georgian government in the domestic arena. The restoration of national dignity, domestic political momentum, and "the heat of street" seemed to have higher priority than the capacity of rational thinking and well-developed planning. ${ }^{57} \mathrm{~A}$ startling example of the dichotomy of Georgia's domestic military agenda has been provided by Geoffrey Wright, who identifies the fact that the formal side of the Georgian objectives aimed at achieving interoperability with NATO forces, in practical terms means forging a military "capable of leveraging a political settlement in the so-called Frozen Conflicts or, if necessary, reoccupying these territories by force." ${ }^{58}$ In this context, as the author argues, the organizational and technical interoperability of Georgian forces with NATO was a desirable effect, but one that was merely of a supportive nature to a primary domestic imperative. For this and other reasons, the policy of confrontation and "menacing rhetoric" led to the advent of the August 2008 war with Russia. ${ }^{59}$

There have been early indications of discrepancy between the formal cooperation process and the practical implementation of policy. For instance, despite the recommen-

55 Minister's Vision 2013-2014, 3.

56 Ibid., 3-8.

57 Till Bruckner, "Decision-Making and Georgia's Perpetual Revolution: The Case of IDP Housing," Caucasian Review of International Affairs 3:2 (2009): 175; Jesse David Tatum, "Democratic Transition in Georgia: Post-Rose Revolution Internal Pressures on Leadership," Caucasian Review of International Affairs 3:2 (2009): 160.

58 Geoffrey Wright, "Defense Reform and the Caucasus: Challenges of Institutional Reform during Unresolved Conflict," Mediterranean Quarterly 20:3 (2009): 20.

59 Dieter Boden, "Conflict Settlement for Abkhazia and South Ossetia: Lessons and Prospects," in South Caucasus - 20 Years of Independence (Berlin: Friedrich-Ebert-Stiftung, 2011), 131. 
dations of the International Security Advisory Board (ISAB) to reduce the actual strength of the armed forces, those actions have never been implemented. To the contrary, the re-equipment of the Georgian Army's Fourth Infantry Brigade and the formation of a new Fifth Brigade run against all agreements and figures agreed upon during the IPAP negotiation round, raising the question of Georgian credibility. ${ }^{60}$ Other authors regarded the rapid increase in the nation's military budget as a clear indication of Georgia's militaristic plans. Kř́ž Zdeněk and Zinaida Shevchuk concluded that the significant share of national GDP ( 8 to 10 percent) spent on army modernization and hardware, when considered along with the character and structure of the forces, indicated the nation's primary motive was to militarily subdue the secessionist regions. ${ }^{61}$ All these considerations are legitimate in the light of Georgia's desperate search for strong security guarantees and the fact of their banal absence. Yet it is far from evident that Georgian authorities would decide in favor of the long path of NATO accession if they had an alternative bilateral military agreement with the U.S. As Hooman Peimani rightly observes, Georgians are very much interested in having a strong U.S. military presence in the country, preferably a large military base. ${ }^{62}$ In the case of a U.S.-Georgia bilateral military agreement being implemented without any precondition of democratic reforms in defense and security, the nation would meet its primary strategic objective - ensuring its physical security - thus eliminating the need and incentive to reform as required by NATO. The war with Russia made it impossible at least in mid-term prospective to pursue the imperative of the domestic agenda - the restoration of territorial integrity. Thus President Saakashvili voiced a sign of changed priorities in early 2009, when he stated "EU membership is more important to us than integration into NATO." 63

Initial steps taken by the newly elected government in 2012 illustrate some visible shift towards granting more recognition to democratic values and a greater awareness of the relevance of democratic change to the process of integration. ${ }^{64}$ However, more has to be done to achieve the required level of interagency cooperation in adjusting Georgia's strategic policy objectives and priorities. On the other hand, the Alliance's priorities and

60 Philipp H. Fluri and Viorel Cibotaru, Defence Institution Building: Country Profiles and Needs Assessments for Armenia, Azerbaijan, Georgia and Moldova (Geneva: DCAF, 2008): 55. The authors note "an increase of 25-30 percent of the figures envisaged in the original IPAP."

61 Kř́ž Zdeněk and Zinaida Shevchuk, "Georgian Readiness for NATO Membership after Russian-Georgian Armed Conflict," Communist and Post-Communist Studies 44:1 (March 2011): 93.

62 Hooman Peimani, Conflict and Security in Central Asia and the Caucasus (Santa Barbara, CA: ABC-CLIO, 2009), 277.

63 Jim Nichol, Georgia (Republic) and NATO Enlargement: Issues and Implications, CRS Report to Congress (Washington D.C.: Congressional Research Service, 6 March 2009), 9; available at http://oai.dtic.mil/oai/oai?verb=getRecord\&metadataPrefix $=$ html\&identifier $=\mathrm{AD}$ A481837.

64 See http://www.government.gov.ge/index.php?lang_id=GEO\&sec_id=269\&info_id=37418; and http://www.government.gov.ge/index.php?lang_id=GEO\&sec_id=269\&info_i $\overline{\mathrm{d}}=36713$. 
organizational dynamics have to be captured as precisely as possible, so as not to fall into the delusion of premature expectations.

Starting from the key message of the Bucharest Summit in 2008, where the issue of granting MAP status to Georgia was sidestepped due to strong internal resistance, the Annual National Program (ANP) was offered by the following ministerial meeting in December 2008 under the strong formulation of "closely watching Georgia's democratic reform progress." Additionally, NATO listed the whole spectrum of areas (military personnel management, transparency of the military budget, etc.) in which Georgia was urged to show better performance. ${ }^{65}$ Here, as well as in the Strasbourg/Kehl Summit Declaration of 2009, any reference to Georgia being offered MAP status was avoided, with the Allies' central focus remaining on the ANP as the core mechanism of assessing Georgia's integration performance. Similar to both declarations, the Lisbon Summit in 2010 did not offer radical improvements with regard to Georgia's hopes. While it acknowledged her membership aspirations, as it also did toward the Balkan countries, this summit declaration made clear that negotiation on MAP remained a distant option. The issue of granting MAP status is of critical importance. While NATO on the one hand denies Georgia any chance of being granted a Membership Action Plan as a firm guarantee of future membership, and urges Georgia to regard the ANP as an alternative mechanism of direct membership, the Alliance has openly extended to countries like Bosnia-Herzegovina an invitation to complete formal preparations to be accepted in the MAP process. ${ }^{66}$ No less important is the structural organization of the documents mentioned, which reveal a significant dwindling of relevance of the topic of enlargement to the Alliance's organizational mission and dynamics. The strain placed on NATO by the ISAF operation in Afghanistan, along with NATO's resource limitations and its military restructuring, have forced NATO HQ to rethink the Alliance's priorities and to lower the priority placed on enlargement plans. Everything seems to indicate that Georgia's path to membership will not be a short one. The reasons for this are twofold. First, the Alliance requires that Georgia undertake deep systemic and institutional reforms in accordance with democratic standards, norms, and values. ${ }^{67}$ Second, it sends signals that expectations of quick membership are futile, and makes clear that the reforms that are requested - even if they are successfully implemented-have to be evaluated in a longterm perspective to ensure Georgia's democratic credibility. ${ }^{68}$

Unfortunately, the domestic debate in Georgia is less concerned with the abovementioned aspects of integration, although the clarity of NATO's strategic messaging

65 "NATO - Chairman's Statement-Meeting of the NATO-Georgia Commission at the Level of Foreign Ministers Held at NATO Headquarters, Brussels," NATO website; available at http://www.nato.int/cps/en/natolive/official_texts_46248.htm.

66 "NATO - Chicago Summit Declaration Issued by the Heads of State and Government Participating in the Meeting of the North Atlantic Council in Chicago on 20 May 2012," NATO website; available at http://www.nato.int/cps/en/natolive/official_texts_87593.htm.

67 "NATO Praises Georgia and Encourages Further Reforms," NĀTO website (27 June 2013); available at http://www.nato.int/cps/en/natolive/news_101669.htm.

68 See http://www.mod.gov.ge/index.php?newsid=2019. 
and preference orderings would greatly benefit the logic and efficiency of policy making in Georgia. While it is seemingly obvious at first glance, the understanding of strategic interests and preferences requires close attention and thorough analysis. The simple logic of the formulation that "the more explicit the guarantee, the greater the likelihood that the commitment will be met" seems to be plausible in the case of Georgia's membership aspirations. ${ }^{69}$ As we have clearly seen, NATO is not ready to offer explicit guarantees to Georgia that would naturally imply an invitation to the MAP process, nor has Georgia regarded NATO integration as the top priority within its security policy realm. These diverging interests have not been compensated by strong incentives that would keep Georgia's ambitions high while encouraging the transformation of its political and defense systems. In a very explicit sense, as the realist school would predict, the gaps in gains caused by cooperation had to be credibly limited or compensated by "sidepayments."70 Again, the North Atlantic Alliance was not able to elaborate credible insurance mechanisms for Georgia against negative relative gains resulting from cooperation, nor was Georgia ready to accept such risks in light of pressing domestic imperatives.

\section{Compliance: The Effect of NATO's Successful Policy of Conditionality}

Social phenomena are generally very difficult to detect and measure. As Walter Powell and Paul DiMaggio have stated, such phenomena "cannot be reduced to aggregation or consequences of individual attributes or motives." 71 The phenomena of political conditionality and compliance do not belong to the category of factors that have been well measured. Though many attempts have been made within the broader framework of Security Sector Reform (SSR) to identify clear mechanisms and areas of indication and measurement, it still remains a formidable challenge to all pioneers grappling with the particular topic of the implementation of external commitments. Countries that are in a similar position to Georgia usually have imposed on them from the outside the norms and procedures that once were domestic properties of constituents of international organization. From this perspective, NATO's standards and procedures are indeed the externalization of those properties. The commitment to comply, curiously, would imply the internalization of once externalized internal properties. ${ }^{72}$ However, the concerns attached to the formation of the Alliance's accession logic are twofold. The first is that the behavioral regime imposed on a candidate is not guaranteed during the pre-membership period. The second is the basic assumption that the behavioral regime imposed on a country by the pre-admission criteria will persist once that country becomes a NATO

69 Thomas S. Szayna, "Chapter Two: The Planning Context," in NATO Enlargement, 20002015: Determinants and Implications for Defense Planning and Shaping, vol. 1243 (Santa Monica, CA: RAND Corporation, 2001), 30.

70 Grieco, "Realist Theory and the Problem of International Cooperation: Analysis with an Amended Prisoner's Dilemma Model," 620.

71 Walter W. Powell and Paul J. DiMaggio, eds., The New Institutionalism in Organizational Analysis (Chicago: University of Chicago Press, 1991), 8.

72 Schimmelfennig, "NATO's Enlargement to the East," 15. 
member. ${ }^{73}$ This assumption is quite problematic. It voluntarily eradicates the risks and negative effects of domestic political structures, which are subject to the changing influences of deep-rooted political traditions and domestic incentives. Stephen Krasner underlines the flawed nature of external influence and draws our attention to the need to change the domestic authority structures through the intensive application of clear and predictable rules, predominantly within the area of institutional capacity building and governance. ${ }^{74}$ The degree of implementation is an imperfect alternative for commitment credibility, but compliance seems to be the best tool available for our undertaking. Mark Kramer claims that NATO has developed disciplinary measures to deter or to punish countries that fall back into undemocratic practices. ${ }^{75}$ Yet, similar to other scholars, he fails to provide clear evidence of such disciplinary mechanisms. We might infer that the broadly stated NATO requirements indeed represent the key areas where assessment teams perform their mission. However, the classified nature of all defense related documents makes our entire effort appear almost futile, unlike the progress reports on the European Neighborhood Policy (ENP) that are regularly posted online. ${ }^{76}$ A significant effort must be made to provide much more clarity about the process of defense transformation in Georgia in light of the process of NATO integration. It would certainly stimulate the proper form of deliberation and public debate as well as a better understanding of the final outcomes.

Referring to NATO's standards, George Katsirdakis (a former senior NATO officer in defense partnership and cooperation) notes the absence of any formally agreed definition of NATO standards, yet he still stresses the common feature - that of a shared understanding of "doing business," of objectives, resource allocation, etc. ${ }^{77}$ We have already noted before the astonishing underrepresentation of NATO standards and requirements in Georgian official documents. Since the notion of defense transformation is very much related to the reorganization of defense policy, priorities, structures, capabilities, training, and even business practices, the application of NATO standards and requirements would mean the same scale of change as was mentioned above. ${ }^{78} \mathrm{We}$ admit that the lack of first-hand information severely damages the reliability of any findings

73 Szayna, "Chapter Two: The Planning Context," 21.

74 Krasner, "International Support for State-Building: Flawed Consensus," 67-69.

75 Kramer, "NATO, the Baltic States and Russia: A Framework for Sustainable Enlargement," 756.

76 Transparency International, "Georgia Has Implemented a Large Portion of the EU Requirements, TI Georgia's New Interim Report Finds," TI Georgia (16 October 2013); available at http://ransparency.ge/en/post/report/georgia-has-implemented-large-portion-eu-requirementsti-georgia-s-new-interim-report-fi. See also "The Office of the State Minister on European and Euro-Atlantic Integration."

77 Ibid., 22-23

78 Daniel Sheldon Hamilton, Transatlantic Transformations: Equipping NATO for the $21^{\text {st }}$ Century (Washington, D.C.: Johns Hopkins/Center for Transatlantic Relations, 2004), 3; available at http://transatlantic.sais-jhu.edu/publications/books/transatlantic_transformations.pdf. See also Hans Binnendijk, Transforming America's Military (Washington, D.C.: National Defense University Press, 2002), 3, 41, 203. 
we present in this essay. Nevertheless, we believe that an intensive (though sporadic) review of secondary sources is still able to provide more than just a general picture of the results achieved by the Georgian government and defense ministry in the last eight years. In 2004, a civilian minister of defense was appointed to head the office, which was also staffed primarily by civilians. Although budget plans have been regularly presented to NATO officials, critics pointed at inadequate legislative oversight. ${ }^{79}$ The critique also highlighted the few checks on executive authority and on the failure to adopt deep institutional reforms. ${ }^{80}$ The level of public involvement in discussing defense-related policy issues has been very low. Similarly, the parliamentary oversight of defense policy formation appeared to be insufficient, rarely having broad discussion on defense priorities and the budgetary plans to meet the strategic and long-term requirements. The mere reference to a small "group of trust" that possessed access to classified information on defense spending and acquisition could not serve as valuable excuse for the existing deficit in participation. ${ }^{81}$ The approval of defense budgets without any detailed review of budgetary appropriations and the required level of coordination with the Ministry of Finance has frequently led to the rapid change of the total budget, revealing inconsistencies with figures previously approved by strategic-level documents (Strategic Defense Review, for instance) ${ }^{82}$ The relationship of the budget to the Status of Defense Transformation document is also questionable, since it raises doubts about its substitutive role for the proper SDR document. ${ }^{83}$ The Planning, Programming and Budgeting System (PPBS) has never been implemented fully, though it was developed in close cooperation with NATO. The current version of Georgia's Strategic Defense Review (SDR) also admits that even though PPBS mechanisms have been in place since 2006, the MOD has not yet managed to make a full transition to PPBS, supposedly due to the low qualifications of MOD personnel. ${ }^{84} \mathrm{An}$ attempt to sidestep the real causes of the failure in implementing PPBS is obvious. The inability of Georgia's MOD to fully implement the system after extensive multilateral efforts in training personnel, especially after six years spent "launching" the system since 2007, would in simple terms imply that either there was no higher level of readiness to implement the system at all, or that the inherent intellectual deficits of the MOD personnel to master the well-known system were too difficult to overcome. The latter is obviously not true. SDR suggests studying the whole defense system again to better address the PPBS control mechanisms of program implementation and procedures. Yet if the main cause of the program's delay was due to the lack of knowledge on the part of MOD personnel, as stressed before in the

79 Nichol, Georgia (Republic) and NATO Enlargement: Issues and Implications, 2-3.

80 Michael D. Mihalka and Mark R. Wilcox, "Unintended Strategic Consequences of Security Assistance in the South Caucasus," Joint Force Quarterly (2010): 26.

81 Fluri and Cibotaru, "Defence Institution Building: Country Profiles and Needs Assessments for Armenia, Azerbaijan, Georgia and Moldova," 60-62.

82 Ibid., 58.

83 "Defence Ministry Becomes Transparent and Status of Transformation."

84 Strategic Defence Review 2013-2016 (Tbilisi: Ministry of Defense of Georgia, 2013), 6; available at http://www.mod.gov.ge/documents/yzqhgsgsreeng.pdf. 
SDR, the appeal to re-launch the revised system appears as nothing more than an attempt to mask the inherent unwillingness of the defense ministry to adopt new planning and budgeting procedures that would establish much higher standards of political and financial accountability, reduce the chance of ineffective practices, and initiate positive change in other state agencies. Similarly, the document highlights the need to improve parliamentary accountability by means of regular reports, yet it falls short of providing clear procedural suggestions. ${ }^{85}$ Finally, some elements of defense planning could be easily made public without any extensive effort to launch PPBS. The Defense Planning Guidance and the summary of Multi-Year Programs constitute a fairly small part of the PPBS. However, once they were made public, they would greatly contribute to the improvement of defense planning transparency, as well as to the involvement of a broader spectrum of the public in the discussion, and thus would generate better political deliberation. To support our findings, we also refer to the budget transparency index, and the anti-corruption index established by Transparency International for Georgia. In 2011, the defense budget's transparency level was assessed as moderate to low. ${ }^{86} 2012$ marked Georgia's transition to the high anti-corruption-index category for defense budgets due to serious shortfalls, risk, and bad practices detected in defense acquisition and personnel promotion, the selective use of disciplinary regulations, and flawed budgetary procedures. ${ }^{87}$

The provisions of the statement of the December 2008 meeting of NATO foreign ministers that called on Georgia to undertake "lessons-learned process from the recent conflict" and also urged the Georgian government to continue reforms in military personnel management, transparency of the defense budget, and other areas can serve as additional and very valuable indication of areas where significant problems have been detected. ${ }^{88}$ As for the issue of the transparency of information to the general public, the MOD ranked at the worst level in 2010, and received an average rating in 2013. ${ }^{89}$ Lastly, the strongly encouraged process of conducting a National Security Reviewwhich was initiated in late 2008 to unify national efforts in rationalizing the security agencies' functions, missions, and capabilities - shows no current signs of life, and is largely stuck in the phase of strategic document revision. ${ }^{90}$ With no consolidated body of

85

The Transparency of National Defence Budgets (London: Transparency International UK, 2011), 22.

87

88 of Foreign Ministers Held at NATO Headquarters, Brussels."

89 ment of Freedom of Information, n.d.); available at http://www.idfi.ge/?cat=researches\& topic=40\&lang=ka. See also 2010 Statistical Results on the Provision of Public Information by 21 State Agencies (Tbilisi: Institute for Development of Freedom of Information, December 14, 2010); available at http://www.opendata.ge/?lang=ka\#!lang/ka/cat/statistic_of_ project/topic/33.

90 
authoritative suggestion to transform the security sector in the long-run in accordance with strict implementation timelines, officially approved by the involved state agencies, the picture of half-hearted Georgian actions would be difficult to get rid off any soon.

All of the factors mentioned above are clear examples of the flawed theoretical assumption that the policy of conditionality will work once formal attributes and conditions for national compliance are established. As Stephen Krasner brilliantly puts it, this account is wrong, since it fails to take into account the incentives for local leaders to impede better governance and does not explain explicitly the particular methods of external contribution to local governance due to its rhetorical commitments to local ownership. ${ }^{91}$ The Georgian case exposes clear evidence of an existing gap between the formal claims of compliance by imitating the patterns of NATO countries and the actual mode of governing. Even if the capacity is the result of foreign assistance and training, it is far from clear why this capacity would be dedicated to developing better practices of governance rather than to "self-serving behavior." 92 The formal adherence to norms and codes of conduct does not result in their automatic implementation in real life, and might even serve the purpose of masking the actual behavior (violation of the norm), as in the case of many countries that sign universal treaties for the sake of their increased legitimating effects. This particular aspect would require additional analysis of the incentives and costs to be expected for a national government as a whole, and government officials in particular, resulting from the application of cooperation conditions. Such an analysis is unfortunately totally absent from the scholarship at present.

\section{Conclusion}

Georgia is obviously not the best example of a Weberian state, which is characterized by the prevalence of rational thinking over the instincts of the moment, and the dominance of bureaucratic neutrality over increased "superexecutivism." ${ }^{93}$ Modernization is the key feature of Georgia's transformation efforts. It replaces the essence of transformation by modernizing the external features of the national governmental structure, and avoids the need for deep-reaching democratic institutional reforms that challenge the position of the nation's power authorities. This modernization pattern makes the preservation of bad practices - such as informal decision making, fluid roles, and leadership's elitist behavior-still possible. As Till Bruckner aptly illustrates in the vivid example of government action to construct camp-villages for refugees, the key feature of Georgian political decision making is the informal nature of the procedures adopted by a close-knit group of functionaries who leave no trail of official records. ${ }^{94}$ It is astounding how little prominence is assigned to formal procedures and norms within the entire process of political decision making. We share Bruckner's conclusion on the inherent contradiction in the Georgian government's reality between having a well-prepared plan and the existing

91 Krasner, "International Support for State-Building: Flawed Consensus," 66.

92 Ibid., 70.

93 Tatum, "Democratic Transition in Georgia," 158-60.

94 Bruckner, “Decision-Making and Georgia's Perpetual Revolution,” 172. 
mode of action. ${ }^{95}$ Understandably, having an actual planning capacity would require clearly established formal procedures that are accepted and followed by all participants within a given institution and between governmental institutions.

NATO is very clear in its strategic messaging around the requirements for aspirant members, but Georgia has failed to apprehend these messages, to address the identity issues more seriously, to declare its policy priorities in response, and to internalize and routinize democratic institutional norms and standards. Since Georgia has not made these adjustments on its own, the cooperation and the conditionality pattern would naturally cause the adjustment of state policies in response to external pressures. ${ }^{96}$ The results of policy adjustment can also be seen in the mode of action the national (Georgian) authorities follow while negotiating with NATO officials. Applying Schimmelfennig's model of negotiation behavior, out of five modes of behavior, two can be identified as most relevant in the Georgian case: those of rhetoric and strategic action. ${ }^{97}$ While pursuing strategic objectives of national security and territorial integrity, the Georgian government has intensively relied on rhetoric and superb bargaining to present the appearance of compliance in order to increase its chances of acceptance by NATO members and/or to speed up the membership process through the imposition of political necessity. The general findings of this article are summarized in Table 2 below. The conclusion, however, would generally conform to Krasner's call for more authorization of external actors by granting them more power of control. This would imply stricter rules of conditionality, better control mechanisms of commitment implementation, as well as better mechanisms for providing higher transparency and public control of policy formulation and implementation in particular. In order to be successful, the concept of conditionality and compliance must heavily rely on the clear identification of "sticks" and "carrots," along with clear timeframes and credible measurement procedures, in order to avoid the risk of formal compliance that masks actual behavior. The reward is clearly the prospect of membership. The reward and incentive must provide higher payoffs than the costs of domestic compliance (internalization). Conversely, the Alliance cannot and should not expand at the cost of losing its common identity, which is based on the shared values of liberal democracy. Since the timeframes for future membership are not defined and the existing mechanisms of conditionality do not account for the successful implementation of national commitments, the mechanisms of the MAP process seem to be the only viable tool that offers greater capacity and authority to ensure Georgia's compliance with Alliance's norms, procedures, standards, and requirements. This suggests that the prospect of NATO membership offers much better prospects for consolidating democratic gains in Georgia and ensuring the proper functioning of state institutions.

95 Ibid., 179.

96 Michael Tierney, "Review of Lisa L. Martin, Democratic Commitments: Legislatures and International Cooperation," The Journal of Politics 64:3 (August 2002): 949.

97

Schimmelfennig, "NATO's Enlargement to the East." 


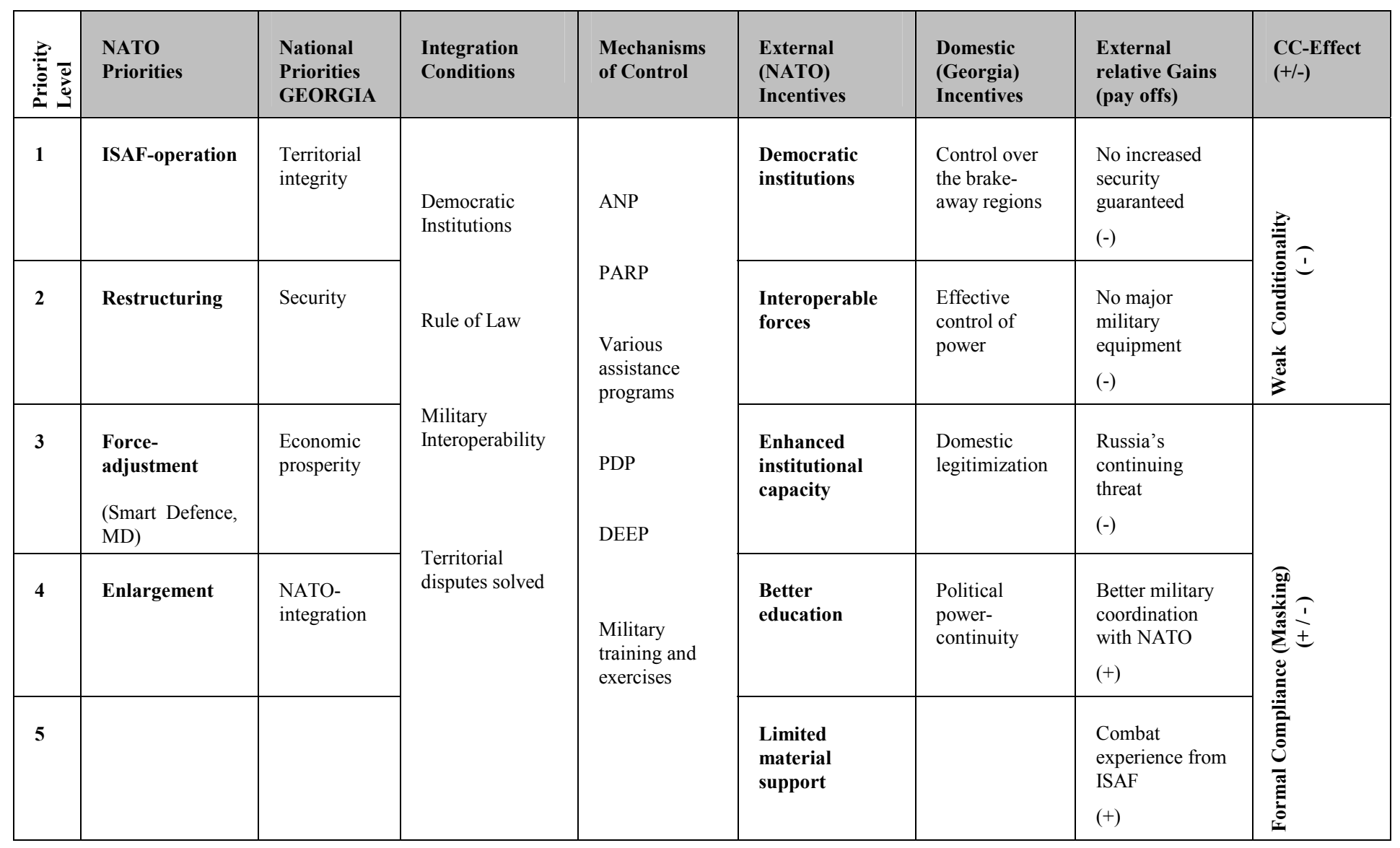




\section{Bibliography}

2010 Statistical Results on the Provision of Public Information by 21 State Agencies. Tbilisi: Institute for Development of Freedom of Information, 2010.

Binnedijk, Hans. Transforming America's Military. Washington, US National Defense University, Center for Technology and NS Policy, 2002.

Boden, Dieter. "Conflict Settlement for Abkhazia and South Ossetia: Lessons and Prospects." In South Caucasus - 20 Years of Independence, 131. Berlin: FriedrichEbert-Stiftung, 2011.

Bruckner, Till. "Decision-Making and Georgia's Perpetual Revolution: The Case of IDP Housing." Caucasian Review of International Affairs 3, no. 2 (2009): 172-180.

Checkel, Jeffrey T.. Compliance and Conditionality In ARENA Working Papers., 2000.

Deepening Relations with Georgia, NATO Backgrounder. Brussels: NATO Public Diplomacy Division, 2013.

Defence Ministry Becomes Transparent and Status of Transformation. Georgian Ministry of Defense, 2013.

Deutsch, Karl W.. "Political Community and the North Atlantic Area." In The European Union: Readings on the Theory and Practice of European Integration. 3rd ed. Boulder, CO: Lynne Rienner Publishers, 1957.

Fluri, Philipp H., and Viorel Cibotaru. Defence Institution Building: Country Profiles and Needs Assessments for Armenia, Azerbaijan, Georgia and Moldova. Geneva: DCAF, 2008.

Georgia Has Implemented a Large Portion of the EU Requirements, TI Georgia's New Interim Report Finds. Georgia: Transparency International, 2013.

Grieco, Joseph M.. "Realist Theory and the Problem of International Cooperation: Analysis with an Amended Prisoner's Dilemma Model." The Journal of Politics 50, no. 3 (1988): 601-03.

Hamilton, Daniel. Transatlantic Transformations: Equipping NATO for the 21st Century. Washington, D.C.: Center for Transatlantic Relations, 2004.

Hemmer, Christopher, and Peter J. Katzenstein. "Why Is There No NATO in Asia? Collective Identity, Regionalism, and the Origins of Multilateralism." International Organization 56, no. 3 (2002): 575-607.

Interview with Georgian Defense Minister Irakli Alasania., 2013. 
Kaufman, Robert G.. "Review of Alan C. Lamborn and Stephen P. Mumme, Statecraft, Domestic Politics, and Foreign Policy Making: The El Chamizal Dispute." The Journal of Politics 51, no. 3 (1989): 790-794.

Kramer, Mark. "NATO, the Baltic States and Russia: A Framework for Sustainable Enlargement." International Affairs 78, no. 4 (2002): 731-56.

Krasner, Stephen D.. "International Support for State-Building: Flawed Consensus." PRISM Security Studies Journal 2, no. 3 (2011): 65-74.

Long, Andrew G., Timothy Nordstrom, and Baek Kyeonghi. "Allying for Peace: Treaty Obligations and Conflict between Allies." The Journal of Politics 69, no. 4 (2007): 10304.

Martin, Lisa L.. Democratic Commitments: Legislatures and International Cooperation. Princeton, NJ: Princeton University Press, 2000.

McFaul, Michael, Amichai Magen, and Kathryn Stoner-Weiss. Evaluating International Influences on Democratic Transitions: Concept Paper. Stanford, CA: Center on Democracy, Development and the Rule of Law, 2007.

Mdinaradze, Ana. Monitoring of Public Info in Geo Ministries. Tbilisi: Institute for Development of Freedom of Information, 2011.

Mihalka, Michael D., and Mark R. Wilcox. "Unintended Strategic Consequences of Security Assistance in the South Caucasus." Joint Force Quarterly (2010): 24-28.

Minister's Vision 2013-2014. Tbilisi: Ministry of Defense of Georgia, 2013.

Moravcsik, Andrew. "Taking Preferences Seriously: A Liberal Theory of International Politics." International Organization 51, no. 4 (1997): 513-553.

National Military Strategy of Georgia., 2007.

National Security Concept of Georgia., 2011.

National Security Review of Georgia., 2011.

NATO - Chicago Summit Declaration Issued by the Heads of State and Government Participating in the Meeting of the North Atlantic Council in Chicago on 20 May 2012. NATO website, 2012.

NATO Praises Georgia and Encourages Further Reforms. NATO website, 2013.

Nichol, Jim. Georgia (Republic) and NATO Enlargement: Issues and Implications In CRS Report to Congress. Washington D.C.: Congressional Research Service, 2009.

Norgaard, Ole. Democracy, Democratization and Institutional Theory In DEMSTAR Research Report., 2001. 
Peimani, Hooman. Conflict and Security in Central Asia and the Caucasus. Santa Barbara, CA: ABC-Clio, 2009.

Pevehouse, Jon C.. Democracy from Above: Regional Organizations and Democratization. Cambridge: Cambridge University Press, 2005.

Powell, Walter W., and Paul J. DiMaggio. The New Institutionalism in Organizational Analysis. Chicago: University of Chicago Press, 1991.

Putnam, Robert D.. "Diplomacy and Domestic Politics: The Logic of Two-level Games." International Organization 42, no. 3 (1988): 427-60.

Reinhard, Janine. "EU Democracy Promotion Through Conditionality in its Neighbourhood: The Temptation of Membership Perspective or Flexible Integration." Caucasian Review of International Affairs 4, no. 3 (2010): 196-213.

Resolution by the Georgian Parliament., 2013.

Schimmelfennig, Frank. NATO's Enlargement to the East: An Analysis of Collective Decision-Making In EAPC-NATO Individual Fellowship Report 2000., 1998.

Strategic Defence Review 2013-2016. Tbilisi: Ministry of Defense of Georgia, 2013.

Sweeney, Kevin, and Paul Fritz. "Jumping on the Bandwagon: An Interest-Based Explanation for Great Power Alliances." The Journal of Politics 66, no. 2 (2004): 42940.

Szayna, Thomas S.. "Chapter Two: The Planning Context." In NATO Enlargement, 2000-2015: Determinants and Implications for Defense Planning and Shaping, 30. Vol. 1243. Santa Monica, CA: RAND Corporation, 2001.

Tatum, Jesse David. "Democratic Transition in Georgia: Post-Rose Revolution Internal Pressures on Leadership." Caucasian Review of International Affairs (2009): 156-171.

The Administration of the President of Georgia. Brussels: NATO Public Diplomacy Division, 2007.

The Transparency of National Defence Budgets. London: Transparency International UK, 2011.

Tierney, Michael. "Review of Lisa L. Martin, Democratic Commitments: Legislatures and International Cooperation." The Journal of Politics 64, no. 3 (2002): 947-956.

Voeten, Erik. "Resisting the Lonely Superpower: Responses of States in the United Nations to U.S. Dominance." The Journal of Politics 66:3 66, no. 3 (2004): 729-754.

Wallander, Celeste A.. "Institutional Assets and Adaptability: NATO after the Cold War." International Organization 54, no. 4 (2000): 705-735. 
Webber, Mark, and Adrian Hyde-Price. Theorizing the North Atlantic Treaty Organization In Joint Sessions of Workshops. Lisbon, 2009.

Webber, Mark. "Theorizing NATO - More than a Defence Alliance?" In NATO at 60: Reflecting on the Past-Anticipating the Future Wednesday., 2009.

Wirtz, James J.. "Review of Patricia A. Weitsman, Dangerous Alliances: Proponents of Peace, Weapons of War." The Journal of Politics 69, no. 1 (2007): 257-259.

Wright, Geoffrey. "Defense Reform and the Caucasus: Challenges of Institutional Reform during Unresolved Conflict." Mediterranean Quarterly 20, no. 3 (2009): 19-39.

Zdeněk, Kř́ž, and Zinaida Shevchuk. "Georgian Readiness for NATO Membership after Russian-Georgian Armed Conflict." Communist and Post-Communist Studies 44, no. 1 (2011): 89-97. 